Article

\title{
Mapping Changes in a Recovering Mine Site with Hyperspectral Airborne HyMap Imagery (Sotiel, SW Spain)
}

\author{
Jorge Buzzi ${ }^{1}$, Asunción Riaza ${ }^{1, *}$, Eduardo García-Meléndez ${ }^{2}$, Sebastian Weide ${ }^{3}$ and \\ Martin Bachmann ${ }^{3}$
}

1 Instituto Geológico y Minero de España (IGME), Geological Survey of Spain, La Calera 1, 28760 Tres Cantos, E-28003 Madrid, Spain; E-Mail: j.buzzi@igme.es

2 Facultad de Ciencias Ambientales, Universidad de León, Campus de Vegazana s/n, E-24071 León, Spain; E-Mail: egarm@unileon.es

3 Remote Sensing Data Centre, German Aerospace Research, Deustsche Zentrum für Luft und Raumfahrt (DLR), P.O. Box 1116, D-82234 Wessling, Germany; E-Mails: sebastianweide@gmx.de (S.W.); martin.bachmann@dlr.de (M.B.)

* Author to whom correspondence should be addressed; E-Mail: a.riaza@igme.es; Tel.: +34-917-287-248; Fax: +34-917-287-202.

Received: 31 October 2013; in revised form: 2 April 2014 / Accepted: 10 April 2014 / Published: 16 April 2014

\begin{abstract}
Hyperspectral high spatial resolution HyMap data are used to map mine waste from massive sulfide ore deposits, mostly abandoned, on the Iberian Pyrite Belt (southwest Spain). Mine dams, mill tailings and mine dumps in variable states of pyrite oxidation are recognizable. The interpretation of hyperspectral remote sensing requires specific algorithms able to manage high dimensional data compared to multispectral data. The routine of image processing methods used to extract information from hyperspectral data to map geological features is explained, as well as the sequence of algorithms used to produce maps of the mine sites. The mineralogical identification capability of algorithms to produce maps based on archive spectral libraries is discussed. Trends of mineral growth differ spectrally over time according to the geological setting and the recovery state of the mine site. Subtle mineralogical changes are enhanced using the spectral response as indicators of pyrite oxidation intensity of the mine waste piles and pyrite mud tailings. The changes in the surface of the mill tailings deserve a detailed description, as the surfaces are inaccessible to direct observation. Such mineralogical changes respond faithfully to industrial activities or the influence of climate when undisturbed by human influence.
\end{abstract}


Keywords: imaging spectroscopy; mine site recovery; change detection; pyrite weathering

\section{Introduction}

Geology-based geoenvironmental mineral deposit models point to the need for "useful geophysical techniques to identify, delineate, and monitor, environmental signatures associated with mined and unmined mineral deposits" [1]. Hyperspectral airborne HyMap data are used in this work to map the extension and evolution of pyrite weathering products in a mine site during the recovery of the mine facilities. Imaging spectroscopy using spectral libraries has been developed as a reliable technique for quick mineralogical analysis of mine wastes, which saves both time and costs versus conventional sample collection [2-6]. Additionally, it permits the mineralogical diagnosis of ephemeral thin crusts concentrating heavy metals on inaccessible surfaces [1], providing an invaluable tool for environmental evaluation and information.

Hyperspectral remote sensing deals with airborne and spaceborne imaging spectrometers with a spectral resolution similar to field or laboratory instruments. A large number of channels in two dimensions requires image processing procedures able to manage the high dimensionality of this data. Algorithms particularly designed to extract spectral features from a large number of data arranged in layers were developed and gathered in widely available software [7]. The new analytical techniques permit a new understanding of the geological expression on the surface of the Earth, which is not accessible through spectral broad band sensors. The spectral resolution of airborne or spaceborne hyperspectral data is similar to field or laboratory spectra. Each pixel of an image is a continuous spectra suitable to be part of a map through digital image processing.

Massive sulfide deposits have been mined in the Iberian Pyrite Belt for at least 5000 years [8]. Mining activity implies the removal of large amounts of rocks, exposing to the air unstable mineral substances that weather when exposed to the atmosphere following a well-known sequence of secondary minerals [9].

Rapid oxidation and evaporation of sulfides on mine waste produces iron-bearing sulfate and other metals as secondary minerals [10]. A sequence of salts is established from a solution of pyrite, from early to later formed [9,11]. Ferrous sulfate salts are found close to pyrite sources (melanterite $\mathrm{Fe}^{2+}\left(\mathrm{SO}_{4}\right) \cdot 7\left(\mathrm{H}_{2} \mathrm{O}\right)$, rozenite $\mathrm{Fe}^{2+}\left(\mathrm{SO}_{4}\right) \cdot 4\left(\mathrm{H}_{2} \mathrm{O}\right)$, szomolnokite $\left.\mathrm{Fe}\left(\mathrm{SO}_{4}\right) \cdot \mathrm{H}_{2} \mathrm{O}\right)$, whereas ferric-bearing minerals (rhomboclase $\mathrm{HFe}^{3+}\left(\mathrm{SO}_{4}\right)_{2} \cdot 4\left(\mathrm{H}_{2} \mathrm{O}\right)$, voltaite, halotrichite $\mathrm{Fe}^{2+} \mathrm{Al}_{2}\left(\mathrm{SO}_{4}\right)_{4} \cdot 22\left(\mathrm{H}_{2} \mathrm{O}\right)$ ) can be considered hydrologic dead-ends, where most of the $\mathrm{Fe}^{2+}$ has had time to oxidize to $\mathrm{Fe}^{3+}$.

Based on laboratory experiments of evaporating acid mine waters, the paragenetic sequence seems as below (p. 152 in [10], mentioning [9]; and "C. Maenz, written communication, 1995"):

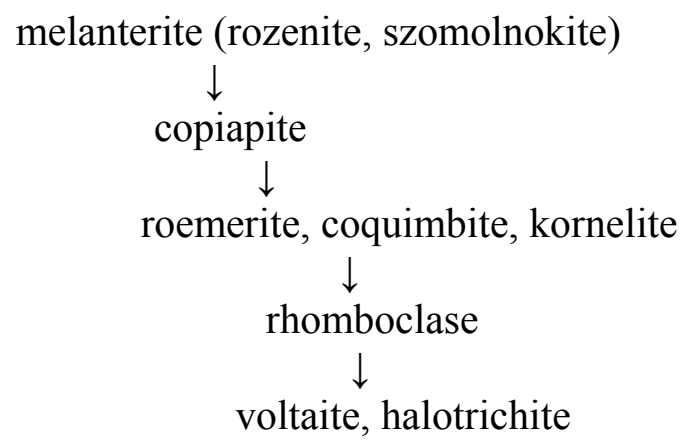


Further oxidation leads to the formation of schwertmannite $\left(\mathrm{Fe}^{3+} 16 \mathrm{O}_{16}(\mathrm{OH})_{12}\left(\mathrm{SO}_{4}\right)_{2}\right)$ and the group of jarosite-alunite $\left(\left(\mathrm{SO}_{4}\right)_{2} \mathrm{KFe}_{3}(\mathrm{OH})_{6}-\mathrm{KAl}_{3}(\mathrm{SO} 4)_{2}(\mathrm{OH})_{6}\right)$. The mineralogy of oxidized zones on gossans is dominated by hematite $\left(\mathrm{Fe}_{2} \mathrm{O}_{3}\right)$, goethite $(\mathrm{FeO}(\mathrm{OH}))$ and jarosite $\left(\left(\mathrm{SO}_{4}\right)_{2} \mathrm{KFe}_{3}(\mathrm{OH})_{6}\right)$.

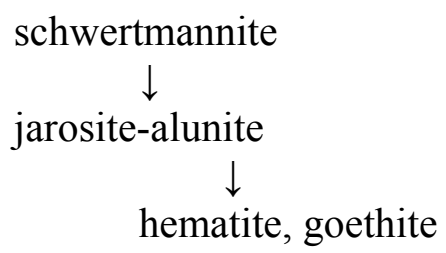

In the mine site of study, industrial activities ended in 2001, and the regional authorities began recovery in 2006. The mineralogical changes involved in mine waste weathering are controlled by climate and geomorphology [12], when undisturbed by human activity. The mineralogical, temporal evolution and spatial pattern of the secondary minerals growing on mine waste range from mud tailings to rock piles and vary also with the landforms on the waste piles and dumps. The waste removal and movement of machinery during the recovery activities has a great influence on the mineralogy of the dust throughout the area [13].

\section{The Mine Site Facilities: Industrial Operation and Recovery}

By now, industrial operation on most metallic mine sites in the Iberian Pyrite Belt has ceased. Most mine facilities are abandoned and under the environmental control of the authorities. There are many such facilities, and the wide regional extent of abandoned mine waste makes the Iberian Pyrite Belt an ideal field for testing environmental monitoring methods.

The operating underground mine works of the Sotiel mine site are displayed along the Odiel River (Figure 1). A conveyor belt transported the ore uphill from the mine to the processing plant. Ashes from the ore processing plant are impounded on an adjacent dam. Pyrite mud is stored in another dam draining to the Odiel River.

In the year 2001, the industrial activities ended. The rehabilitation of the mine site began in 2006 with the ash dam. The purpose of the rehabilitation is to isolate the contaminating matter, preventing its expansion into the environment. The water of the dam has been drained and the bottom protected to prevent water infiltration, which can activate the oxidation process of pyrite. The dry bottom has been sealed with a repeated sandwich of several layers, including an overlying textile sheet, a clay-rich layer, an iron oxide rich layer and an organic matter rich layer. Grass is planted with Poaceae over the final organic matter layer to restore ordinary soil development. The dry grass (flight 4 August 2008) growing in spring is cut in the summer to prevent fires (flight 13 August 2009).

The rehabilitation of the mill tailings dam and the dismantlement of the ore processing plant began in the autumn of 2008 and continued during the winter of 2009. By 13 August 2009, the last HyMap flight available, the mud had been removed from the dam, and the bottom was in the process of being drained and consolidated before the operation of machines. In the following years, the bottom was sealed, the dam was filled with waste from the mine dumps, and the final surface was covered with yellow sand.

Hyperspectral image processing provides a fast and accurate diagnosis of the secondary minerals growing on mine waste and their mineralogical changes mapped from HyMap flights in the test site in 
the summers of 2005, 2008 and 2009 [13-15]. Previously published work discusses the challenges and limitations in validating mineralogical analysis in a highly spatially heterogeneous environment, combined with fast temporal geochemical mobility [16].

Figure 1. The location of the study area in the Iberian Hesperian Massif (Spain and Portugal) (blue circle) [17]. The location of domains within the Sotiel mine site.
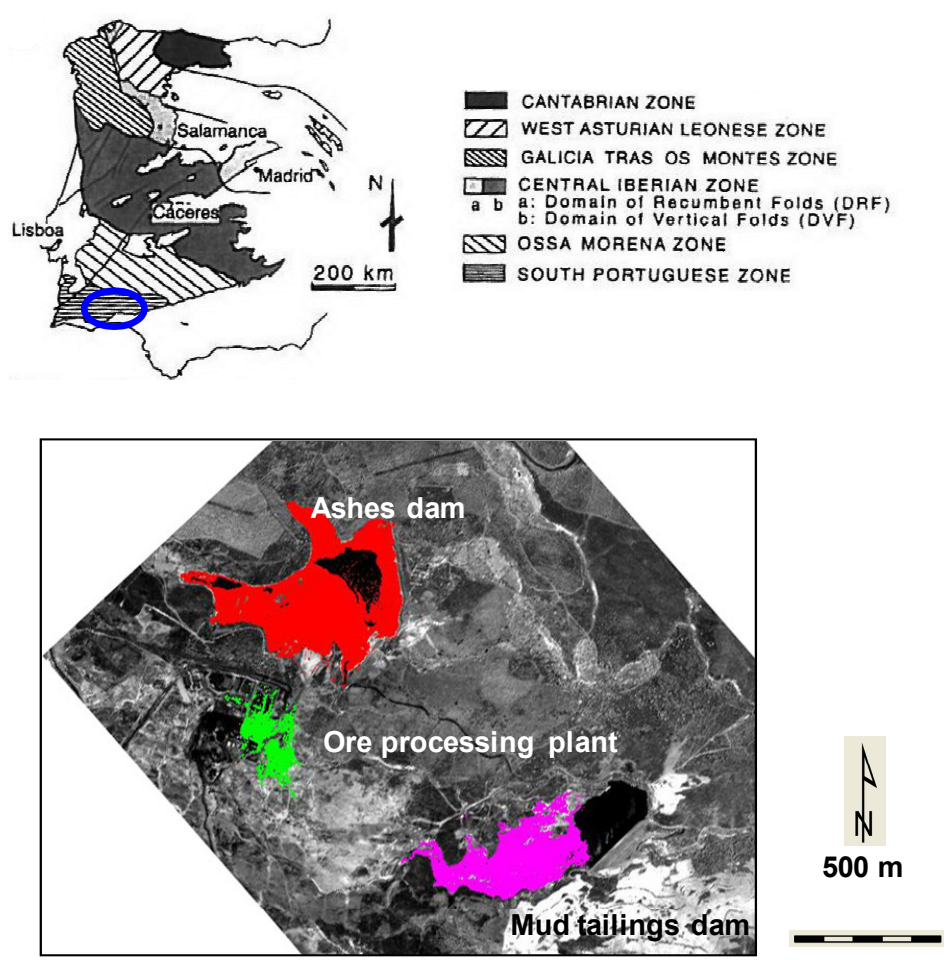

\section{Data Set}

HyMap airborne hyperspectral images were acquired over the Odiel River path on 17 July 2005, 4 August 2008, and 13 August 2009. HyMap is an airborne hyperspectral sensor with 128 wavebands from 436 to $2485 \mathrm{~nm}$ with a spectral resolution of $15 \mathrm{~nm}$ in the $436-125 \mathrm{~nm}$ wavelength range, $13 \mathrm{~nm}$ in the 140-180 $\mathrm{nm}$ wavelength range and $17 \mathrm{~nm}$ in the 195-248 wavelength range. Its spatial resolution is $5 \mathrm{~m}$. The HyMap preprocessing was described in [12] and its use in mineral diagnosis of crusts over mine waste in [16].

Field spectral measurements were taken at 287 field locations on the mine sites with an ASD FieldSpec 3 Spectrometer [18] from 2008 to 2011 for thematic purposes, apart from calibration. An additional 45 spectral measurements were made in a dark room on selected samples of rock, mud and soil. This device measures the ground reflectance spectra covering the wavelength range from $350 \mathrm{~nm}$ to $2500 \mathrm{~nm}$. The details of the procedure for diagnosing spectra using spectral reference libraries $[14,19,20]$ in the area have also been previously published [21]. Eighteen existing spectra from sulfide oxidation products in public domain spectral libraries [10,22] were used as references with the Spectral Analyst [7] to get a comparative score of similarity both for spectra measured in the field and HyMap data. The Spectral Angle Mapper, Spectral Feature Fitting and Binary Encoding were taken into account in equal weighting in the final similarity score with a maximum of 1 . General trends and small changes in mineralogical identification can thereby be traced in detail. 
Selected representative sediment and rock samples were analyzed by X-ray diffraction (XRD). All XRD measurements were performed using a PANalytical powder diffractometer (PANanalytical, Almelo, The Netherlands) with $\mathrm{Cu} \mathrm{K \alpha}$ radiation. Selected samples of rocks, mud and dust were also collected for conventional mineralogical analysis.

\section{Geological Mapping through Image Processing}

The procedure for feature extraction for thematic purposes used in this research is an interpreter oriented sequential spectral unmixing using standard algorithms, leading to a spatial pattern and spectral identification pixels within the scene displayed as a map. The dimensionality of the data is reduced through various image processing within subscenes extracted at several steps through the chain of image processing, ending in a map of the pyrite oxidation products of the abandoned mine site [12].

The first step uses a false color composite of HyMap Channels $10(0.5719 \mu \mathrm{m}), 39(1.0063 \mu \mathrm{m})$ and $125(2.4702 \mu \mathrm{m})$ to build a spectral library with basic land use end-members on the scene (Figure 2A). Channel 10 focuses on water properties, Channel 39 on vegetation and Channel 125 on land. Minimum Noise Fractions are used to explore the general land use features. Areas mainly covered by vegetation, clear water and urban areas were excluded from the analysis from this step on, after masks were built based on the spectral identification of the main land use regions through the Spectral Angle Mapper (Figure 2B,C). Then, the Spectral Angle Mapper produces again a first estimation of the spectral diversity of the open land, which is used as a mask for subsequent image processing steps per scene. This is the beginning of the long and iterative image processing procedure ending in a map, with the major steps shown in Figure 2.

The areas mapped as open land during the first step are analyzed using Minimum Noise Fraction Transforms, subsequent Pixel Purity Index [23] and $n$-dimensional analysis. The mine sites and main areas covered by the sulfate salts are commonly identified from bare open and cultivated land at this stage (Figure 2D). The data dimensions are reduced further, repeating the procedure to qualify areas within early-formed salts and among the more oxidized or hydrated zones (Figure 2E,F), which are isolated on corresponding masks (Figure $2 \mathrm{G}-\mathrm{I}$ ). A final map is compiled by gathering all the end members corresponding to pyrite oxidation products on the scene (Figure 2K). A spectral library is finally built with such end members, which are then mineralogically identified by comparison to a selection of mineral spectra from archive spectral libraries (Figure 2J), previously resampled to match the HyMap wavelength ranges.

Spectral Angle Mapper, Spectral Feature Fitting and Binary Encoding were taken into account using equal weights for each of the final similarity scores. The Spectral Angle Mapper determines the spectral similarity between two spectra by calculating the angle between spectra, treating them as vectors in a space with dimensions equal to the number of bands [24]. A maximum angle of 0.1 radians is used as the default. Spectral Feature Fitting compares the fit of image spectra to selected reference spectra using a least-squares technique [25]. The Binary Encoding algorithm encodes the data and end member spectra into zeros and ones, based on whether a band falls below or above the spectrum mean [26].

The spectrally dominant mineral was assigned to the map units (Figure $2 \mathrm{~K}$ ) using the mean spectra of the corresponding region of interest through the image processing procedure, using the spectral library with pyrite oxidation and precipitation products $[7,19,20]$ as a reference. 
Figure 2. Sequential subscenes produced by image processing (from left to right). (A) False color composite with HyMap Channels $9(0.5568 \mu \mathrm{m}), 28(0.8460 \mu \mathrm{m})$ and 109 $(2.2074 \mu \mathrm{m})$. (B) Land use map estimating vegetation cover and open soil. (C) Mask for vegetation. (D) Mask for mine waste. (E) Mask for hydrated tailings. (F) Mask for oxidated dumps. (G) Mask for hydrated ponds around the ore processing plant. (H) Mask for the hydrated mill tailings dam. (I) Mask for the oxidated pond of ashes. (J) Spectral reference library on pyrite weathering products $[19,20]$. Spectra are displaced vertically for clarity. (K) Final map of coatings of pyrite weathering products over mine waste following the reference spectral library [19]. Color coding for minerals mapped with the corresponding chemical formula are arranged in a precipitation and oxidation sequence. Increasing reddish colors suggest intense oxidation. Bluish and greenish colors concentrate on hydrated areas.
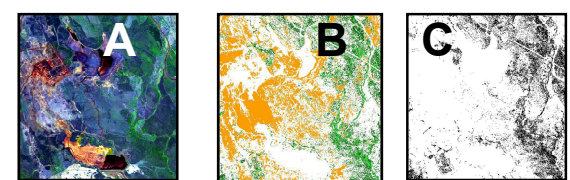

green vegetation wood and pasture open soil
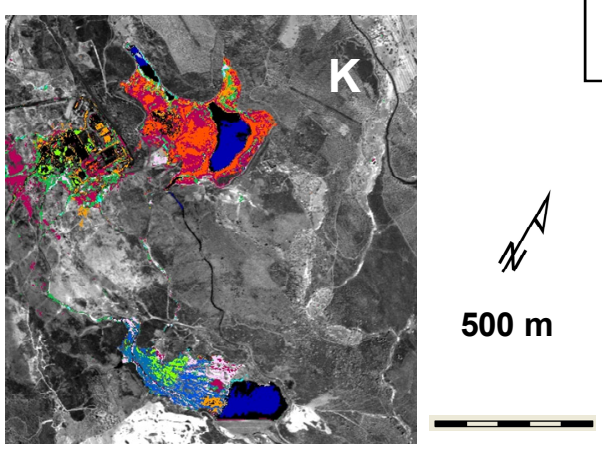

$500 \mathrm{~m}$
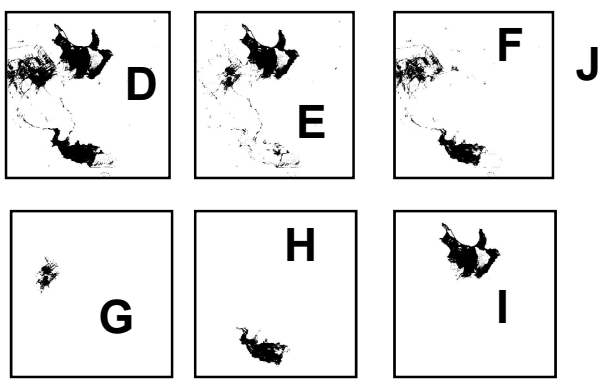

Hematite

Goethite

Ferrihydrite

Jarosite

Alunite

Gypsum

Fibroferrite

Epsomite

Schwertmannite

Halotrichite

Rhomboclase

Pickeringite

Paracoquimbite

Copiapite

Ferricopiapite

Szmolnokite

Rozenite

Melanterite
$\mathrm{Fe}_{2} \mathrm{O}_{3}$

$\mathrm{FeO}(\mathrm{OH})$

$\mathrm{Fe}^{3+}{ }_{2} \mathrm{O}_{3} \cdot 0.5\left(\mathrm{H}_{2} \mathrm{O}\right)$

$\left(\mathrm{SO}_{4}\right)_{2} \mathrm{KFe}_{3}(\mathrm{OH})_{6}$

$\mathrm{KAl}_{3}\left(\mathrm{SO}_{4}\right)_{2}(\mathrm{OH})_{6}$

$\mathrm{SO}_{4} \mathrm{Ca} .2 \mathrm{H}_{2} \mathrm{O}$

$\mathrm{Fe}^{3+}\left(\mathrm{SO}_{4}\right)(\mathrm{OH}) \cdot 5\left(\mathrm{H}_{2} \mathrm{O}\right)$

$\mathrm{MgSO}_{4} \cdot 7\left(\mathrm{H}_{2} \mathrm{O}\right)$

$\mathrm{Fe}^{3+} 16 \mathrm{O}_{16}(\mathrm{OH})_{12}\left(\mathrm{SO}_{4}\right)_{2}$

$\mathrm{Fe}^{2+} \mathrm{Al}_{2}(\mathrm{SO} 4)_{4} \cdot 22\left(\mathrm{H}_{2} \mathrm{O}\right)$

$\mathrm{HFe}^{3+}\left(\mathrm{SO}_{4}\right)_{2} \cdot 4\left(\mathrm{H}_{2} \mathrm{O}\right)$

$\mathrm{MgAl}_{2}\left(\mathrm{SO}_{4}\right)_{4} \cdot 22\left(\mathrm{H}_{2} \mathrm{O}\right)$

$\mathrm{Fe}^{3+}{ }_{2}\left(\mathrm{SO}_{4}\right)_{3} \cdot 9\left(\mathrm{H}_{2} \mathrm{O}\right)$

$\mathrm{Fe}^{2+} \mathrm{Fe}^{3+}{ }_{4}\left(\mathrm{SO}_{4}\right)_{6}(\mathrm{OH})_{2} \cdot 2 \mathrm{O}\left(\mathrm{H}_{2} \mathrm{O}\right)$

$\mathrm{Fe}^{3+}{ }_{0.6666}{ }^{\mathrm{Fe} 3+}{ }_{4}\left(\mathrm{SO}_{4}\right)_{6}(\mathrm{OH})_{2} \cdot 2 \mathrm{O}\left(\mathrm{H}_{2} \mathrm{O}\right)$

$\mathrm{Fe}\left(\mathrm{SO}_{4}\right) \cdot \mathrm{H}_{2} \mathrm{O}$

$\mathrm{Fe}^{2+}\left(\mathrm{SO}_{4}\right) \cdot 4\left(\mathrm{H}_{2} \mathrm{O}\right)$

$\mathrm{Fe}^{2+}\left(\mathrm{SO}_{4}\right) \cdot 7\left(\mathrm{H}_{2} \mathrm{O}\right)$

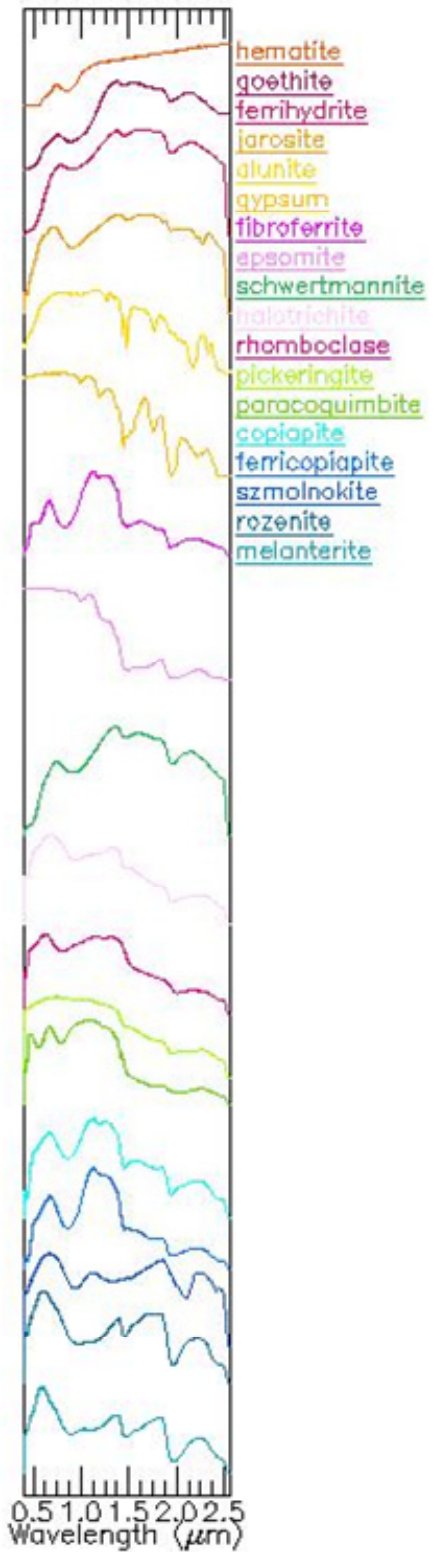


The Spectral Angle Mapper [24] was used to test the scene similarity from the second step, helping to identify end members more representative of sulfate salt coverage according to field experience and digital comparison of the shape of the corresponding spectra with archive spectral libraries. Therefore, the spectral shape information was also derived from the HyMap data.

A number of individual mineral substances precipitated from pyrite acid water were identified using public domain spectral libraries, ranging from melanterite, the first-formed sulfate, to hematite, when dehydration and oxidation is completed. Eighteen existing spectra of sulfide oxidation products in public domain spectral libraries [19,20] were used as references with the Spectral Analyst [7] to get a comparative score of similarity for spectra from every map unit. The Spectral Angle Mapper, Spectral Feature Fitting and Binary Encoding were taken into account using equal weights for each of the final similarity scores. The spectrally dominant mineral was assigned to the map units using the mean spectra of the corresponding region of interest through the image processing procedure, using the spectral library with pyrite oxidation and precipitation products.

Although mineral identification of hyperspectral pixels necessarily involves reducing high dimensionality spectral data to one compositional class, in reality, pixels are rarely pure, and their spectral signatures often reflect heterogeneous forms of mixing. Both field and laboratory spectral experience from samples collected in the mine site show that most spectral features are mixed responses from the selected minerals, which are likely to occur. Only very extended and spatially well-developed pans of intensely oxidized pyrite mud show clearly identifiable spectral signatures compared to the archive spectral libraries. The oxidation of pyrite is a progressive and heterogeneous process concerning mineralogical phases and spatial cover, as well as grain size or minor shade effects associated with small-scale geomorphology. The areas identified on the imagery as a single or double mineral presence should be interpreted as indicators of a mineralogically dominant trend displayed by HyMap imagery with a 5-m spatial resolution.

\section{Mineralogical Changes Associated with Mine Site Recovery Shown by HyMap Maps}

\subsection{The Ash Dam}

In June 2005, the northern ash pond was deeply oxidized, as can be seen in the image (Figure 3A). Hematite and goethite are widespread on the surface with reddish colors, both in the field and the maps. Comparatively, more hydrated phases occur along the rills as pickeringite or paracoquimbite, whitish in the field and bluish and greenish on the maps.

Field spectra (Figure 4A) reveal the dominant oxidized crusts in 2005 (Figure 4C), according to the results of the HyMap image processing (see Figure 3A). The reddish dominant color in the map of 2005 over the dam of ashes, suggesting an intense oxidation (Figure 3A), is due to the presence of hematite and goethite. The typical spectral features of hematite recorded in reference spectral libraries [20] are faithfully drawn by field spectra (Figure 4A).

The rehabilitation of the ash dam was begun in 2006 and was completed by the summer of 2008 . All the ashes were removed, the water was drained, and the whole area was refilled, thus preventing water infiltration. In August 2008, the surface of the former ash dam was covered by high dry grass and remained so in the following years (Figure 3B,C). 
Field spectra (Figure 4A) show the spectral changes from a dominant hematitic crust in 2005 (Figure 4C) to dry grass in 2008 (Figure 4D). The spectra of dry grass covering the former ash dam in 2008 measured in the field (Figure 4A) shows the typical decedent vegetation spectral response. HyMap spectra (Figure 4B) from the spectral libraries used as end members to compile the maps in Figure 3A,B in the ash dam reproduce faithfully the spectra measured in the field in 2005 and 2008.

Figure 3. (a-c) Maps compiled from HyMap data on the mineral products of the oxidation and dehydration of sulfide sludge, on the three available flights around the ore processing plant. (A-C) Maps compiled from HyMap data on the mineral products of the oxidation and dehydration of sulfide sludge over the mine site, on the three available flights. Increasing reddish colors suggest intense oxidation. Bluish and greenish colors concentrate on hydrated areas.

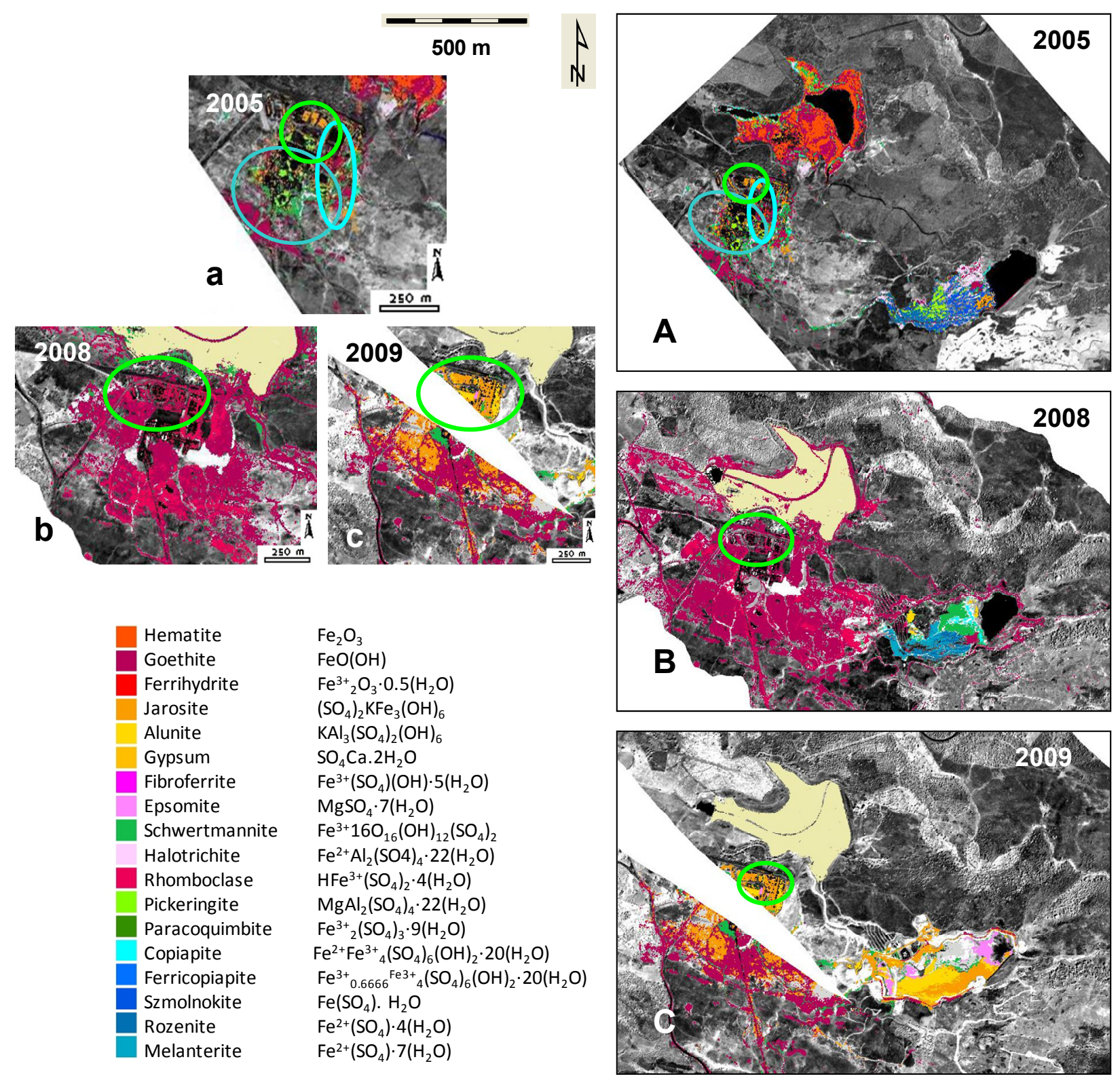


Figure 4. Ash dam. (A) Field spectra from dominant hematite in the ash dam in 2005 and dry grass in 2008 covering the former ash dam. (B) HyMap spectra from dominant hematite in the ash dam in 2005 and dry grass in 2008 covering the former ash dam. (C) Detail of dominant hematite crusts covering the ash dam in 2005, with spectra in A. (D) Detail of dry grass covering the recovered former ash dam in 2008, with spectra in A. (E) View of dominantly hematitic crusts covering the ash dam in 2005. (F) View of the dry grass covering the former ash dam in 2008 , with operator measuring spectra.
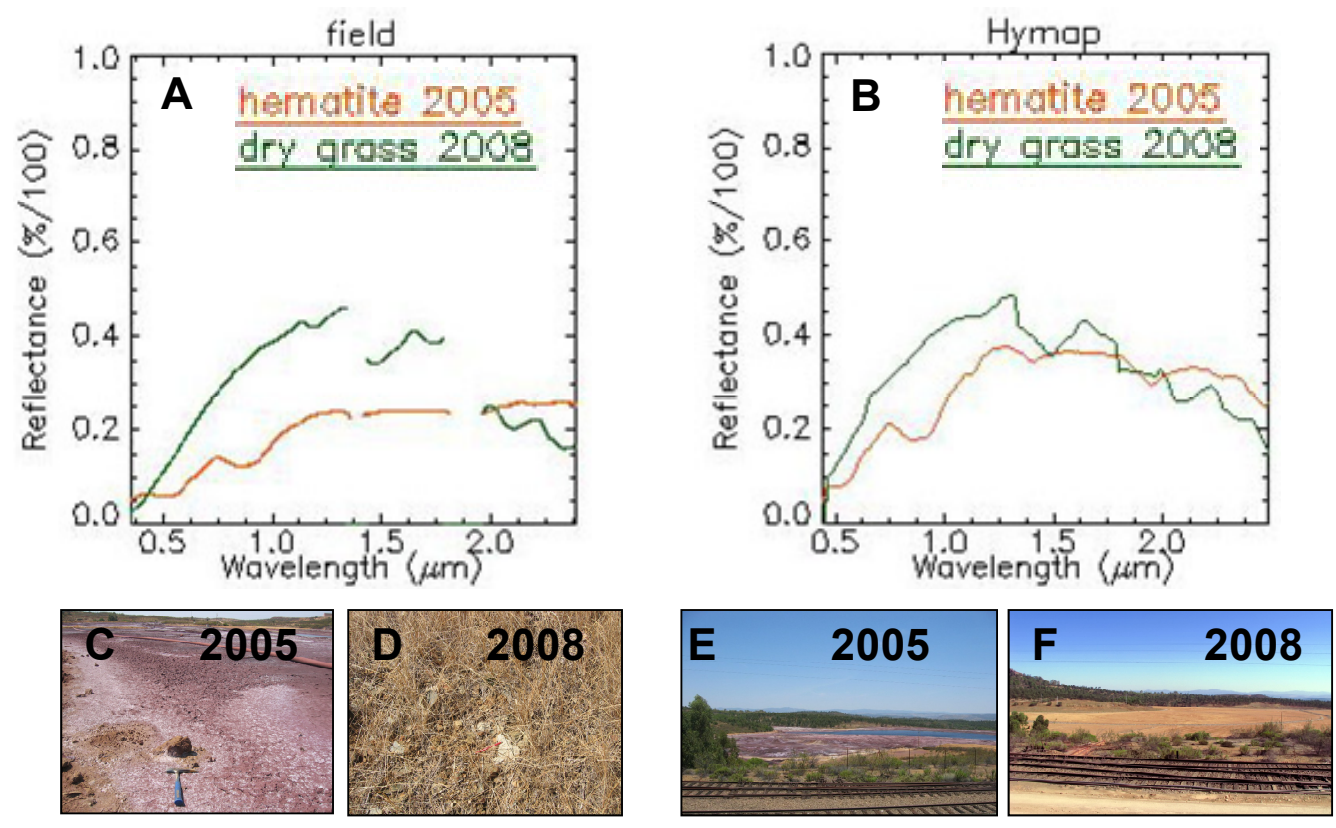

\subsection{The Ore Processing Plant and Neighborhood}

The ore processing plant stopped its industrial activity in 2001. All buildings and waste ponds around remained abandoned until 2006, when the recovery of the nearby ash dam began.

In 2005, the processing plant was covered by hydrated sulfate, such as paracoquimbite and pickeringite, covering the dumps around the buildings and in small ponds (Figure 3A, cyan circle) storing mill waste. Spots of oxidized iron sulfate, in the form of jarosite, and of hydroxides, as goethite (Figure 3A, green circle), cover the outer areas of the facilities.

No activity within the buildings of the plant has occurred since 2001, but some influence from moving the machinery around can be expected after 2006. The HyMap 2008 flight shows the ore processing plant and neighborhood intensely oxidized by the movement of machinery (Figure 3B), cleaning of small mud ponds and cleaning and smoothing of slopes on the dumps around the plant and the ash dam. Goethite and ferrihydrite cover the entire area. The small ponds around the plant storing mud in 2005 have disappeared by 2008.

The dismantling of buildings and machinery began during the fall of 2008 and progressed through the winter and spring of 2009. In the summer of 2009, the movement of machinery and the removal of parts in the processing plant was still active. The map of August 2009, shows the surfaces of the buildings in the plant covered by jarosite, alunite and some schwertmannite (Figure 3C, green circle), while the neighborhood of the processing plant is covered by goethite over the already cleaned dumps and rock outcrops. In 2009, the intensity of oxidation recedes from its level in 2008, both around the 
ore processing plant and the roads around the mill tailings plant, a level which had been caused by the movement of machines involved in the recovery.

\subsection{The Mill Tailings Dam}

Mapping the surface of the mill tailings dam with hyperspectral data is crucial, as there is a large mass of mud which is inaccessible to direct observation. The mineralogy of the thin crusts on the surface of the mass of mud is sensitive to water or mud supplies, whether by industrial operations, maintenance or climate variability.

The industrial activities of the ore processing plant ceased in 2001. Both the pond of ashes and the mill tailings dam kept a steady waste storage, but the maintenance of the facilities included water pumping and flowing through the water bodies. The water from the ash pond was drained to the mill tailings dam until 2006 through a channel (Figure 5A, red arrow). A mud cleaning plant at the foot of the wall of the mill tailings dam prevents the contamination of water downstream and returns processed mud behind the wall to the tailings dam (Figure 5B, red arrow). The artificial water supply at known channel outputs influences the pattern of mineral coatings over the surface of the mill tailings, as much as do the climate parameters and the natural progressive drying up of the mass of mud tailings after the industrial waste supplies stop.

The surface of the mill tailings dam was covered by dominantly hydrated sulfate crusts in 2005 and 2008 , covering a mud mass. The mud was already removed in the summer of 2009 , and the map shows a comparatively oxidized bottom, already drying and compacting.

\subsubsection{The Influence of Water and Mud Operational Supplies: From 2005 to 2008}

In 2005, the minerals coating the surface of the mill tailings were intensely hydrated, dominated by rozenite and szomolnokite (Figure 5A, green circle). A fan of uniform pickeringite spreads from the output of the draining channel (Figure 5A, blue circle) supplying water from the dam of ashes (Figure 5A, red arrow). The mud is comparatively shallower at this point, and the outer coating is comparatively more oxidized than the general mass of mud tailings around it. Oxidized crusts, goethite and jarosite, are located far from the water supply, close to the border of the water of the pond (Figure 5A, red circle), surrounded by comparatively more hydrated halotrichite (Figure 5A, orange circle).

The ash dam was cleaned in 2006, and the draining of water to the mill tailings dam stopped. A water cleaning plant at the foot of the wall of the dam prevents the spread of contamination to runoff. In 2008, the only water was supplied by two pipes at both ends of the wall of the mill tailings dam, pumping water from the water cleaning plant at the foot of the wall (Figure 5A,B, red arrows). The area covered by the most hydrated sulfate is strongly dependent on the location of the water supplied by the maintenance of facilities.

The lack of water supply from the ash dam in 2008 erased the pickeringite surface visible in 2005 where there was a water floodgate (Figure 5B, blue circle), it was replaced by a copiapite and alunite tail in 2008, when the topographically most elevated area by the former water floodgate was covered by a uniform surface of alunite (Figure 5B, cyan circle). 
Figure 5. The mill tailings dam: (A-C) Maps compiled from HyMap data on the minerals product of oxidation and dehydration of sulfide sludge, on the three available flights on the southern mill tailings dam. Color coding for minerals mapped with the corresponding chemical formula are arranged in a precipitation and oxidation sequence. Bluish and greenish colors concentrate on comparatively hydrated areas. Orange and dark red color corresponds to oxidized end members. Acid water stored behind the wall of the dam is in black. Red arrows are the locations of the mud supply. (D) Panoramic view of the mill tailings dam.
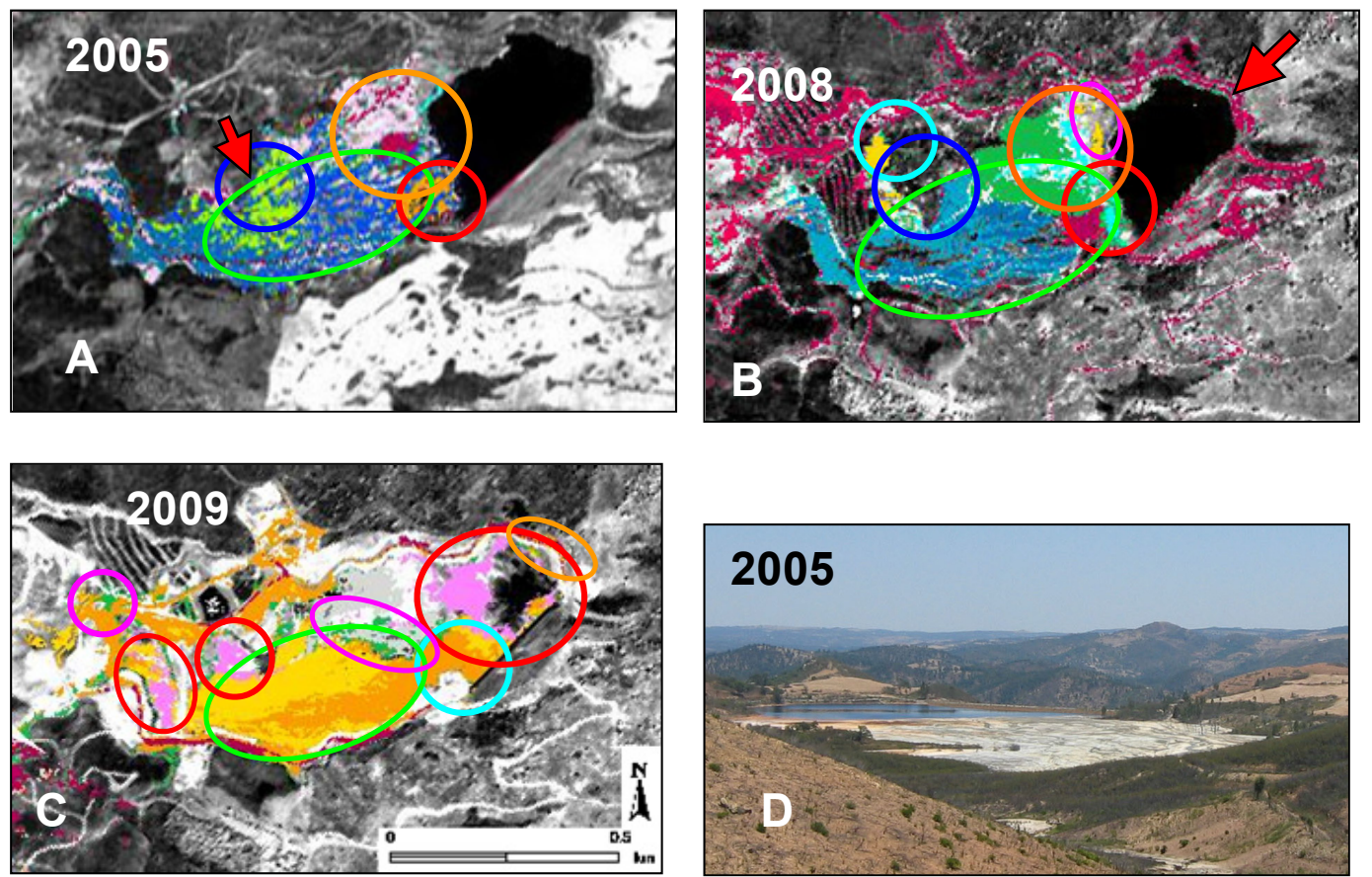

\begin{tabular}{|c|c|}
\hline Hematite & $\mathrm{Fe}_{2} \mathrm{O}_{3}$ \\
\hline Goethite & $\mathrm{FeO}(\mathrm{OH})$ \\
\hline Ferrihydrite & $\mathrm{Fe}^{3+}{ }_{2} \mathrm{O}_{3} \cdot 0.5\left(\mathrm{H}_{2} \mathrm{O}\right)$ \\
\hline Jarosite & $\left(\mathrm{SO}_{4}\right)_{2} \mathrm{KFe}_{3}(\mathrm{OH})_{6}$ \\
\hline Alunite & $\mathrm{KAl}_{3}\left(\mathrm{SO}_{4}\right)_{2}(\mathrm{OH})_{6}$ \\
\hline Gypsum & $\mathrm{SO}_{4} \mathrm{Ca} .2 \mathrm{H}_{2} \mathrm{O}$ \\
\hline Fibroferrite & $\mathrm{Fe}^{3+}\left(\mathrm{SO}_{4}\right)(\mathrm{OH}) \cdot 5\left(\mathrm{H}_{2} \mathrm{O}\right)$ \\
\hline Epsomite & $\mathrm{MgSO}_{4} \cdot 7\left(\mathrm{H}_{2} \mathrm{O}\right)$ \\
\hline Schwertmannite & $\mathrm{Fe}^{3+} 16 \mathrm{O}_{16}(\mathrm{OH})_{12}\left(\mathrm{SO}_{4}\right)_{2}$ \\
\hline Halotrichite & $\mathrm{Fe}^{2+} \mathrm{Al}_{2}(\mathrm{SO} 4)_{4} \cdot 22\left(\mathrm{H}_{2} \mathrm{O}\right)$ \\
\hline Rhomboclase & $\mathrm{HFe}^{3+}\left(\mathrm{SO}_{4}\right)_{2} \cdot 4\left(\mathrm{H}_{2} \mathrm{O}\right)$ \\
\hline Pickeringite & $\mathrm{MgAl}_{2}\left(\mathrm{SO}_{4}\right)_{4} \cdot 22\left(\mathrm{H}_{2} \mathrm{O}\right)$ \\
\hline Paracoquimbite & $\mathrm{Fe}^{3+}{ }_{2}\left(\mathrm{SO}_{4}\right)_{3} \cdot 9\left(\mathrm{H}_{2} \mathrm{O}\right)$ \\
\hline Copiapite & $\mathrm{Fe}^{2+} \mathrm{Fe}^{3+}{ }_{4}\left(\mathrm{SO}_{4}\right)_{6}(\mathrm{OH})_{2} \cdot 2 \mathrm{O}\left(\mathrm{H}_{2} \mathrm{O}\right)$ \\
\hline Ferricopiapite & $\mathrm{Fe}^{3+}{ }_{0.6666}{ }^{\mathrm{Fe} 3+}{ }_{4}\left(\mathrm{SO}_{4}\right)_{6}(\mathrm{OH})_{2} \cdot 2 \mathrm{O}\left(\mathrm{H}_{2} \mathrm{O}\right)$ \\
\hline Szmolnokite & $\mathrm{Fe}\left(\mathrm{SO}_{4}\right) \cdot \mathrm{H}_{2} \mathrm{O}$ \\
\hline Rozenite & $\mathrm{Fe}^{2+}\left(\mathrm{SO}_{4}\right) \cdot 4\left(\mathrm{H}_{2} \mathrm{O}\right)$ \\
\hline Melanterite & $\mathrm{Fe}^{2+}\left(\mathrm{SO}_{4}\right) \cdot 7\left(\mathrm{H}_{2} \mathrm{O}\right)$ \\
\hline
\end{tabular}

\subsubsection{Effects of Mud Removal and Drying Up: 2009}

The recovery of the mill tailings dam began in the autumn of 2008, through 2011. The mill tailings were actively drained and dried during the winter and spring of 2009. In the summer of 2009 (Figure 5C), the surface of the mill tailings dam was dry and accessible by foot, in the process of consolidation to allow the operation of machinery. 
The area formerly flooded behind the wall in 2005 and 2008 was in 2009 largely covered by halotrichite (Figure 5C, red circles). Halotrichite patches occur where mud remains behind the walls at the bottom, which were covered by mud in 2005 and 2008 (Figure 5C, red circles). Drying due to recovery activities during 2009 caused the generalized oxidation of the mineral coatings to jarosite and alunite (Figure 5C, green circle) with schwertmannitic outer fringes (Figure 5C, magenta circles), replacing the hydrated szomolnokite, rozenite and melanterite dominating the surface of the tailings in 2005 and 2008 (Figure 5A,B, green circles).

\subsubsection{The Influence of Climate: From 2005 to 2008}

The progressive dehydration and oxidation of the secondary minerals of the mill tailings dam from 2005 to 2008 is evidenced by the increasing extent of oxidized crusts. The year 2005 was dryer and warmer than 2008 [27]. The effects of the increasing temperature and less moisture available in 2005 are visible in the mineralogy of the coatings on the surface of the mill tailings dam in the areas away from channel outputs.

Rainwater and mass movements inside the mill tailings developed a micro-geomorpho-geology with rills and minor ridges. Most of the surface of the dam in 2008 was covered by szomolnokite grooved by channels (Figure $5 \mathrm{~B}$, green circle) with a bottom of rozenite, a slightly more hydrated sulfate. The topographically lower areas host small patches of copiapite.

The surface of the main mud mass that in 2005 was covered by rozenite and szomolnokite (Figure 5B, green circle), in 2008, was dominated by melanterite, rozenite and copiapite (Figure 5B, green circle). This surface of hydrated minerals shrunk its extension from 2005 due to the lack of water supplies from the ash dam. Since the mud tailings mass had been moving without mud supplies since 2006, the rills and ridges are better developed in the upper surface of coatings over the mud tailing mass in 2008 than in 2005. The pattern of mineralogical crusts shows a strong topographical control both in 2005 and 2008. In 2008, melanterite dominates the western tail, and rozenite draws the more hydrated rills, while copiapite traces the less humid rills.

Halotrichite in 2005 changed its pattern of secondary minerals in 2008 (Figure 5A,B, orange circle) near the water pool behind the wall of the dam. There is a wide uniform surface of schwertmannite in comparatively topographically elevated areas over a lower copiapitic bottom drawing a topographic valley draining to the pond of water. This schwertmannite and copiapite topographically controlled area in 2008 replaces the szomolnokite and halotrichite from 2005, showing an increasing oxidation process.

In the border close to the water, there is a stripe of alunite in 2008 (Figure 5B, magenta circle). This spatial pattern of schwertmannite and copiapite extends southwards, replacing a small jarosite area from 2005 (Figure 5A,B, red circle). This jarositic area was the most oxidized spot in 2005, the far end of the water supply at the time, and by 2008 has moved to the northern border of the water pond, a comparatively topographically high spot concentrating increasing oxidation processes.

\subsubsection{Spectral Analysis}

The spectra from the end members used to map the mineral crusts with the HyMap data are mineralogically diagnosed using a reference spectral library and specific algorithms (see Section 3). The HyMap spectra of the crusts mapped in the mud tailings dam (Figure 6) illustrate the 
mineralogical evolution following both the industrial operation changes and climate effects. The spectra in 2008 and 2009 (Figure 6A,B) reflect the dominant presence of hydrated sulfate crusts covering the mass of the mill tailings dam (alunite, pickeringite, copiapite and rozenite). In 2005, a warm year, goethite and gypsum occur (Figure 6A), which were absent in the spectra of the crust units mapped in 2008 (Figure 6B).

Most crusts present in 2008 are diagnosed as hydrated sulfate in the HyMap data (Figure 6B). The spectra from the hydrated sulfate, rozenite and melanterite show enhanced absorption features compared to those in 2005, indicating a wider extent and increased availability of water in 2008.

The HyMap spectra of the identified units in 2009 (Figure 6C), when the mud was already removed, show the presence of comparatively oxidized mineral crusts (goethite and jarosite). The more hydrated sulfate units in 2009 are diagnosed as alunite and schwertmannite as the first choice. However, the second diagnosed minerals are oxidized mineralogical phases (jarosite and goethite), indicating a progressing oxidation, even on the most hydrated ends.

Figure 6. The mill tailings dam. Spectra from HyMap areas mapped in (A) June 2005, (B) August 2008, and (C) August 2009. Spectra are arranged on a precipitation and oxidation sequence. The color coding follows the trend of the key from Figure 3, but changes are made for clarity.
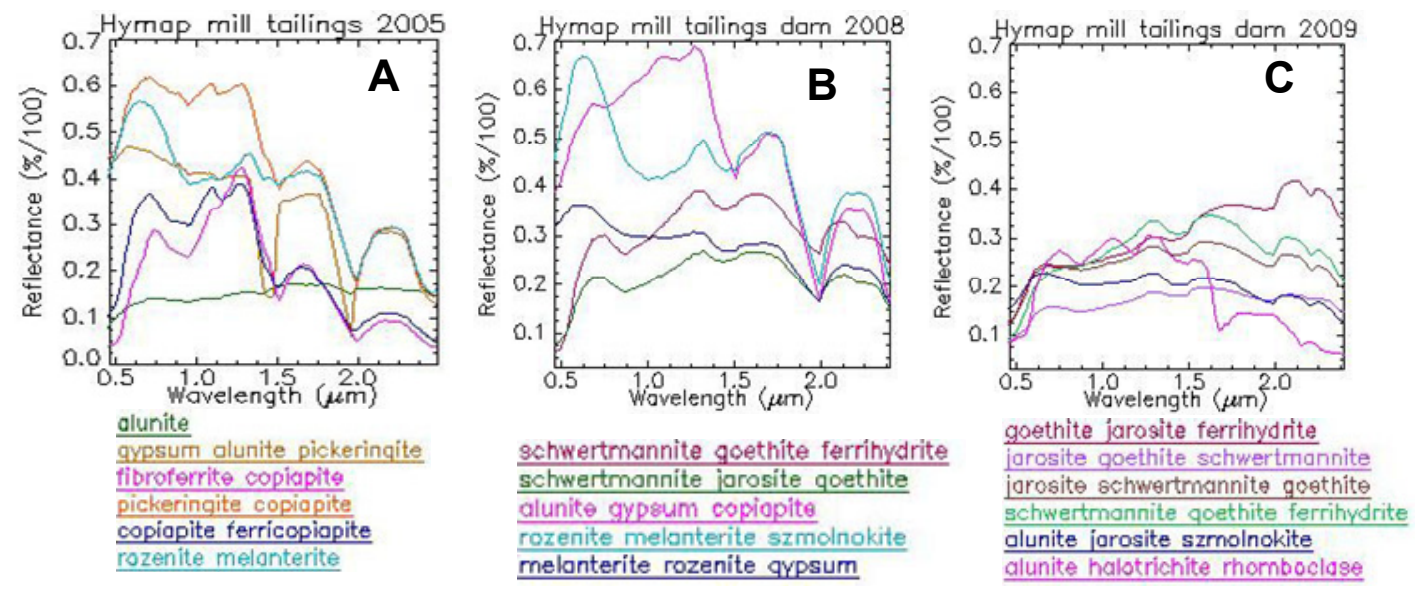

\section{Discussion}

Although the mineral identification of hyperspectral data necessarily involves reducing the spectral data, with its high dimensionality, to one compositional class, in reality, pixels are rarely pure, and their spectral signatures often reflect heterogeneous forms of mixing. Both field and laboratory spectral experience from samples collected at the mine site show that most spectral features are mixed responses from the selected minerals, which are likely to occur. Only extended and spatially well-developed pans of intensely oxidized pyrite mud show clearly identifiable spectral signatures compared to the archive spectral libraries. The oxidation of pyrite is a progressive and heterogeneous process concerning sulfate crusts and spatial cover, as well as grain size or minor shade effects associated with small-scale geomorphology. The areas identified in the imagery as a single or double mineral presence should be interpreted as indicators of a mineralogically dominant trend displayed by the HyMap imagery with a 5-m spatial resolution. 
Prior work monitored the mineralogical changes on mine waste within this mine site considering geomorphological influences under climate variability [15]. HyMap flights from 1999 to 2005 were used to support the observations. This work, in contrast, concentrates on the mineralogical effects induced in the mine site by an intense recovery activity running from 2006 to 2009 [7-9], which is still ongoing.

The complete recovery of the ash dam opens up the possibility of monitoring future changes by the long-term spectral study of the vegetation growing over the recovered premises.

Both the progressing work on the mill tailings dam and the ore processing plant illustrate the mineralogical trends associated with changes due to the activities of recovery. The active cleaning of crusts over dumps is translated spectrally to an intense oxidation evident in 2008 around the ore processing plant, which recedes partly with the removal of buildings and machinery in 2009 .

On the mill tailings dam, the changes on the locations of water supply are critical for the pattern of mineralogical coatings on the upper crust of the mud mass. The depth of mud is also partly responsible for the mineralogy of the crusts on the surface. The lack of water and mud supplies lets the mud mass movement display a minor geomorphology in the surface, which is directly translated to mineralogical changes obvious from 2005 to 2008.

This work confirms that imaging spectroscopy fills the need of "useful geophysical techniques to identify, delineate, and monitor, environmental signatures associated with mined and unmined mineral deposits" [1]. Image processing should be tailored per scene and per domain within a mine site; otherwise, complex spatial mineralization patterns cannot be resolved. These patterns are critical for accurate interpretation of climate change trends, metal contamination estimations or acid drainage prediction. Maps that are derived from individual subscenes and processed using independent processing procedures broadly agree with each other with respect to changes in oxidation and dehydration mineral phases. Areas covered by vegetation types and other obscuring land use/cover types had to be masked in order to achieve reasonable results for pyrite oxidation mineral trends.

There are strong limitations to validating mapping data using conventional chemical analysis, due to its high spatial heterogeneity and fast temporal mobility. Spectral behavior trends extracted from the images and in the laboratory from geological evaluations can provide reliable indicators for monitoring contamination from mine wastes. The challenges and limitations mapping pyrite oxidation products over mine waste dealing with preprocessing procedures, heterogeneous mineral mixtures and spectral diagnostic methods are already widely discussed [11].

\section{Conclusions}

The industrial activity at the mine of Sotiel-Almagrera (Huelva) stopped in the year 2000. The recovery by the regional government began in 2006 with the closure of the ash dam and was still active in 2011. The HyMap 2005 flight pictures the state of the facilities before any recovery activity, with an intensely oxidized ash dam, a comparatively hydrated mud tailings dam and oxidized buildings of the ore processing plant surrounded by crusts of hydrated sulfate on small mud ponds.

The HyMap 2008 flight shows the ash dam covered by dry grass, completely recovered, and the surroundings clean, free from any pyrite weathering product, which has been mechanically cleaned over the dumps. The ore processing plant and neighborhood are intensely oxidized by the movement of 
the machinery and the cleaning of the small mud ponds. The mud tailings dam is still dominatingly hydrated, although some progress in oxidation can be seen at the mud supply locations, which have ceased operation since the closure of the ash dam.

In 2009, the mud from the mill tailings dam was removed, and the state of oxidation in the crusts is intermediate, as much as the ore processing plant and surroundings, where buildings and machinery are already in the process of being dismantled. The movement of machinery throughout the facilities makes the oxidation state of the whole surface appear uniform in the imagery.

The micro-geomorphology controls the mineralogical coatings on the surface of masses of mill tailings, when there are no artificial supplies of water or mud. The same is true on rock piles of larger dimensions, where minor slopes and topographically low areas are more sensitive and display the mineralogical changes associated with climate variability.

This proves that hyperspectral imagery is an invaluable witness to the changes experienced by abandoned mine sites, whether under the influence of climate and the availability of environmental humidity or under intense human activity.

\section{Acknowledgments}

The National Research Plan of Spain (CGL2007-60004/CLI, BES-2008-003648) has funded this work. Both the German Space Agency (Oberpfaffenhofen, Bayern) and the University of Nantes (France) provided training in advanced spectral analytical techniques (Short Stages SEST2009010937 and SEST1000I001495XVO). Jose Manuel Moreira contributed with information about mine inventories and regional environmental databases. The Andalusian Regional Government, the Junta de Andalucía, permitted entry to the abandoned mine site of Sotiel at the border of the river. Local industries also allowed access to the river through their facilities.

\section{Author Contributions}

Jorge Buzzi, Asunción Riaza and Eduardo García-Meléndez shared all the interpretative image processing, field geological work and geological interpretation. Sebastian Weide and Martin Bachmann were involved in the flight survey planning and the advanced pre-processing of all HyMap data, and supported the image analysis.

\section{Conflicts of Interest}

The authors declare no conflict of interest.

\section{References}

1. Plumlee, G.S. The environmental geology of mineral deposits. Part A: Processes, techniques, health issues. Rev. Econ. Geol. 1999, 6, 71-116.

2. Swayze, G.A.; Smith, K.S.; Clark, R.N.; Sutley, S.J.; Pearson, R.M.; Vance, J.S.; Hageman, P.L.; Briggs, P.H.; Meier, A.L.; Singleton, M.J.; et al. Using imaging spectroscopy to map acidic mine waste. Environ. Sci. Technol. 2000, 34, 47-54. 
3. Choe, E.; van der Meer, F.; van Ruitenbeek, F.; van der Werff, H.; de Smeth, B.; Kim, K. Mapping of heavy metal pollution in stream sediments using combined geochemistry, field spectroscopy, and hyperspectral remote sensing: A case study of the Rodalquilar mining area, SE Spain. Remote Sens. Environ. 2008, 112, 3222-3233.

4. Goetz, A.F.H. Three decades of hyperspectral remote sensing of the Earth: A personal view. Remote Sens. Environ. 2009, 113, 5-16.

5. van der Meer, F.D.; van der Werff, H.M.A.; van Ruitenbeek, F.J.A.; Hecker, C.A.; Bakker, W.H.; Noomen, M.F.; van der Meijde, M.; Carranza, E.J.M.; de Smeth, J.B.; Woldai, T. Multi- and hyperspectral geologic remote sensing: A review. Int. J. Appl. Earth Obs. Geoinf. 2012, 14, $112-128$.

6. Quental, L.; Sousa, A.J.; Marsh, S. Identification of materials related to acid mine drainage using multi-source spectra at S. Domingos Mine, southeast Portugal. Int. J. Remote Sens. 2013, 34, 1928-1948.

7. Exelis. ENVI User's Guide; Exelis Visual Information Solutions: Boulder, CO, USA, 2011.

8. Leblanc, M.; Morales, J.A.; Borrego, J.; Elbaz-Poulichet, A. 4,500-year-old mining pollution in Southwestern Spain: Long-term implications for modern mining pollution. Econ. Geol. 2000, 95, 655-662.

9. Buurman, P. In vitro weathering products of pyrite. Geol. Mijnvouw 1975, 54, 101-105.

10. Nordstrom, D.K.; Alpers, C.N. Geochemistry of Acid Mine Waters. In The Environmental Geochemistry of Mineral Deposits. Part A: Processes, Techniques, and Health Issues; Plumlee, G.S., Logsdon, M.J., Eds.; Society of Economic Geologists: Littleton, CO, USA, 1999; pp. 133-160.

11. Alpers, C.N.; Nordstrom, D.K.; Spitzley, J. Extreme Acid Mine Drainage from a Pyritic Massive Sulfide Deposit: The Iron Mountain Endmember. In Environmental Aspects of Mine-Wastes; Jambor, J.L., Blowes, D.W., Ritchie, A.I.M., Eds.; Mineralogical Association of Canada: Quebec City, QC, Canada, 2003; pp. 407-430.

12. Riaza, A.; Müller, A. Hyperspectral remote sensing monitoring of pyrite mine wastes: A record of climate variability (Pyrite Belt, Spain). Environ. Earth Sci. 2010, 61, 575-594.

13. Buzzi, J. Imaging Spectroscopy to Evaluate the Contamination from Sulphide Mine Waste in the Iberian Pyrite Belt Using Hyperspectral Sensors (Huelva, Spain). Ph.D. Thesis, Universidad de León, León, Spain, 14 December 2012.

14. Buzzi, J.; Carrère, V.; Riaza, A.; García-Meléndez, E.; Bachmann, M. Modified Gaussian Modelization Applied to Hyperspectrtal Data in an AMD-Contaminated Area: Case of Odiel River (Huelva, SW Spain). In Proceedings of the 7th EARSeL Workshop on Imaging Spectroscopy, Edinburgh, UK, 11-13 April 2011.

15. Buzzi, J.; Riaza, A.; García-Meléndez, E.; Holzwarth, S. Change Detection in Sediments of a River Affected by Acid Mine Drainage Using Airborne Hyperspectral Hymap Data (River Odiel, SW Spain). In Proceedings of the 4th EARSeL Workshop on Remote Sensing and Geology, Mykonos, Greece, 24-25 May 2012; pp. 134-158.

16. Riaza, A.; Buzzi, J.; García-Meléndez, E.; Carrère, V.; Müller, A. Monitoring the extent of contamination from acid mine drainage in the Iberian Pyrite Belt (SW Spain) using hyperspectral imagery. Remote Sens. 2011, 3, 2166-2186.

17. Gibbons, W.; Moreno, T. The Geology of Spain; Geological Society: London, UK, 2002. 
18. Analytical Spectral Devices, Inc. ASD, FieldSpec ${ }^{\circledR} 3$ User Manual, ASD Document 600540 Rev. F; Analytical Spectral Devices, Inc.: Boulder, CO, USA, 2006.

19. Crowley, J.K.; Williams, D.E.; Hammarstrom, J.M.; Piatak, N.; Chou, I.-M.; Mars, J.C. Spectral reflectance properties $(0.4-2.5 \mu \mathrm{m})$ of secondary Fe-oxide, Fe-hydroxide, and Fe-sulphate-hydrate minerals associated with sulphide-bearing mine wastes. Geochem. Explor. Environ. Anal. 2003, 3, 219-228.

20. Clark, R.N.; Swayze, G.E.; Wise, R.; Livo, E.; Hoefen, T.; Kokaly, R.; Sutley, S.J. USGS Digital Spectral Library Splib06a; U.S. Geological Survey: Reston, VA, USA, 2007.

21. Riaza, A.; Garcia-Melendez, E.; Mueller, A. Spectral identification of pyrite mud weathering products: A field and laboratory evaluation. Int. J. Remote Sens. 2011, 32, 185-208.

22. Clark, R.N.; Swayze, G.A.; Gallagher, A.; King, T.V.V.; Calvin, W.M. The U.S. Geological Survey Digital Spectral Library: Version 1: 0.2 to $3.0 \mu \mathrm{m}$; U.S. Geological Survey: Reston, VA, USA, 1993.

23. Boardman, J.W. Automated Spectral Unmixing of AVIRIS Data Using Convex Geometry Concepts. In Proceedings of the Summaries of the 4th JPL Airborne Geoscience Workshop, Washington, DC, USA, 25-29 October 1993.

24. Kruse, F.A.; Lebkoff, A.B.; Boardman, J.B.; Heidebrecht, K.B.; Shapiro, A.T.; Barloon, P.J.; Goetz, A.F.H. The Spectral Imaging Processing System (SIPS)—Interactive Visualization and Analysis of Imaging Spectrometer Data. Remote Sens. Environ. 1993, 44, 145-163.

25. Clark, R.N.; Gallagher, A.J.; Swayze, G.A. Material Absorption Band Depth Mapping of Imaging Spectrometer Data Using the Complete Band Shape Least-Squares Algorithm Simultaneously Fit to Multiple Spectral Features from Multiple Materials. In Proceedings of the 3rd Airborne Visible/Infrared Imaging Spectrometer (AVIRIS) Workshop, Pasadena, CA, USA, 20-21 May 1991.

26. Goetz, A.F.H.; Vane, G.; Solomon, J.E.; Rock, B.N. Imaging spectrometry for earth remote sensing. Science 1985, 228, 1147-1153.

27. Agencia Estatal de Meteorología, Spain (AEMET). Resumen Anual Climatológico de los años 2004, 2005, 2006, 2007, 2008 y 2009. Available online: http://www.aemet.es (accessed on 11 April 2014).

(C) 2014 by the authors; licensee MDPI, Basel, Switzerland. This article is an open access article distributed under the terms and conditions of the Creative Commons Attribution license (http://creativecommons.org/licenses/by/3.0/). 